\title{
ОПТИМИЗАЦИЯ РЕЗУЛЬТАТОВ ЛЕЧЕНИЯ ГЛУБОКИХ НЕКРОЗОВ ПУТЕМ РАЦИОНАЛЬНОЙ НЕКРЭКТОМИИ В ЭКСПЕРИМЕНТЕ
}

\author{
(С Лазаренко В.А., Мишустин В.Н., Квачахия Л.Л., Моновцов И.А. \\ Кафедра хирургических болезней ФПО \\ Курского государственного медицинского университета, Курск \\ E-mail: vladimirshef2011@yandex.ru
}

\begin{abstract}
Проблема лечения больных с глубокими некрозами кожи и мягких тканей остается актуальной. Выбор объема некрэктомии, сроков ее проведения, границ выполнения хирургических разрезов до сих пор окончательно не решен. Некрэктомия на фоне введения комбинации DSLET (10 мкг/кг) и серотонина адипината (4,5 мг/кг) приводила к уменьшению выраженности и распространенности альтернативных изменений при моделировании глубоких некрозов кожи и мягких тканей. На 3-и сутки в краях раны формируется грануляционная ткань. К концу эксперимента вся зона повреждения выполнена соединительной тканью, в которой обнаруживаются новообразованные плотные коллагеновые волокна, что свидетельствует о созревании соединительной ткани в формирующемся рубце. Предложенная методика приводит к максимальному снижению летальности до 16,6\%, а также снижает летальность животных на 10,9\% по сравнению с опытной группой без выполнения некрэктомии.
\end{abstract}

Ключевые слова: некрэктомия, глубокий некроз, морфологическое исследование, флуометрия, биохимические показатели.

\section{OPTIMIZATION OF THE DEEP NECROSIS TREATMENT RESULTS SUPPORTED BY RATIONAL NECRECTOMY IN THE EXPERIMENT \\ Lazarenko V.A., Mishustin V.N., Kvachakhiya L.L, Monovtsov I.A.}

Post-Graduate Surgery Department of Kursk State Medical University, Kursk

The problem of managing patients with deep necrosis of the skin and soft tissue remains relevant. Selecting necrectomy volume, timing of its implementation, the boundaries of performing surgical incisions are still not fully resolved. Necrosectomy against the background of the DSLET combination $(10 \mathrm{mg} / \mathrm{kg})$ and serotonin adipate $(4.5 \mathrm{mg} / \mathrm{kg}) \mathrm{resulted}$ in a decrease in the severity and prevalence of alternative changes in simulating deep necrosis of the skin and soft tissues. On the $3 \mathrm{~d}$ day the granulation tissue was formed in wound edges. By the end of the experiment the whole damage area was formed by connective tissue with the newly produced dense collagen fibers indicating the maturation of connective tissue in the generating scar. The suggested method results in a maximum decrease in mortality to $16.6 \%$ and also reduces the lethality of animals by $10.9 \%$ as compared to the experimental group without necrectomy.

Keywords: necrectomy, deep necrosis, morphological examination, flowmetry, biochemical parameters.

В связи с развитием медицины при глубоких некрозах кожи и мягких тканей, в частности вызванных ожогами и отморожениями III степени, приоритет стал отдаваться активной хирургической тактике, предусматривающей выполнение при таких травмах некрэктомии (НЭ) $[3,4,5]$. Bce это позволяет существенно сократить количество вынужденных первичных радикальных ампутаций, при этом спектр хирургической активности при глубоких некрозах сместился в сторону выполнения хирургической НЭ $[4,5]$.

До сих пор определение сроков проведения НЭ, ее объемов при глубоких некрозах остается предметом дискуссий [1].

Ряд авторов считают целесообразным выполнение ранних НЭ с последующим местным лечением ран, проведением реконструктивных операций на заключительном этапе [2, 4, 5]. Однако регламентация сроков и объемов проведения таких хирургических вмешательств остаются спорными $[1,2,5]$.
Дискутабельным остается и вопрос о проведении разрезов при иссечении некротических тканей, ряд хирургов предпочитают проводить разрезы на границе мертвой и живой ткани, при этом возможно удаление жизнеспособной ткани. Перспективным в этом направлении является возможность применения лекарственных веществ, позволяющих уменьшить зону некроза и дифференцировать границу мертвых и жизнеспособных тканей $[1,4,5]$.

Цель исследования: улучшение результатов лечения глубоких некрозов кожи и мягких тканей путем оптимизации сроков и объема некрэктомии на фоне комбинированного применения селективного антагониста дельта опиоидных рецепторов и серотонинергического препарата.

\section{МАТЕРИАЛЫ И МЕТОДЫ ИССЛЕДОВАНИЯ}

Исследование выполнено на половозрелых крысах-самцах линии «Wistar», массой тела 250 г. 
Операции и все манипуляции с крысами проводились в условиях общего обезболивания, путем внутрибрюшинного введения хлоралгидрата в дозе 300 мг/кг (табл. 1).

Изучение глубокого некроза кожи и подлежащих мягких тканей проводили на модели контактного отморожения кожи по методу Бойко B.В. (2010 г.), так как данная методика позволяет в $100 \%$ случаев получить гистологически доказуемый результат [5].

На 3-и сутки после моделирования контактного отморожения экспериментальным животным контрольной группы 2 и опытным группам 4 под наркозом острым путем выполняли некрэктомию. После удаления некротизированной ткани применялась шовная методика сближения раны непрерывным обвивным швом атравматической полипропиленовой нитью № 00000. Повязку на раневую поверхность не накладывали.

Крысы опытной группы получали внутрибрюшинно серотонина адипинат в дозе 4,5 мг/кг и комбинированно внутрибрюшинно DSLET 10 мкг/кг после моделирования некроза на первые, третьи, пятые и седьмые сутки.

Животных выводили из эксперимента на 3, 7 и 14-е сутки передозировкой хлоралгидрата и осуществляли забор тканей. Исследовали состояние поврежденных тканей на поверхности и разрезе, визуально учитывали особенности их строения. Для гистологического исследования брали 4-5 кусочков ткани из видимой области повреждения и из пограничной области. Кусочки ткани фиксировали в 10\% растворе формалина на фосфатном буфере $(\mathrm{pH} 7,2-7,4)$ в течение двух дней, заливали в парафин, изготавливали срезы толщиной 4-5 мкм, окрашивали гематоксилином и эозином и по методу Ван Гизона.

Выраженность воспалительных процессов оценивали по количественному содержанию интерлейкина-6 (ИЛ-6) и фактора некроза опухоли-альфа (ФНО- $\alpha)$, которые определяли с помощью наборов для иммуноферментного анализа для крыс («Rat TNF- $\alpha$ Platinum ELISA» и «Rat IL-6 Platinum ELISA» фирмы «еBioscience», Австрия).
Измерение микроциркуляции на коже спины экспериментального животного проводили с помощью лазерного допплеровского флоуметра (ЛДФ) фирмы «Biopac Systems, Inc.» MP-100 c датчиком TSD-144 и программы Acqknowledge 3.8.1. Измерение показателей микроциркуляции выполнялось на пограничной некрозу зоне в 6 точках. Показатели имели вид ЛДФ-грамм и выражались в перфузионных единицах (п.е.). Запись проводилась в течение 30 сек. в каждой точке.

Выраженность перекисного окисления липидов в крови животных оценивали по содержанию малонового диальдегида (МДА). Кроме того, определяли активность каталазы, супероксиддисмутазы (СОД) и общую антиокислительную активность (ОАА) сыворотки крови крыс. Уровень конечных стабильных метаболитов оксида азота (суммарную концентрацию нитратов и нитритов, NOx) определяли колориметрическим методом по развитию окраски в реакции диазотирования нитритом сульфаниламида, входящим в состав реактива Грисса.

Количественное содержание провоспалительных цитокинов интерлейкина-6 (ИЛ-6), фактора некроза опухоли-альфа (ФНО- $\alpha)$ определяли с помощью ИФА наборов для крыс «Rat TNF- $\alpha$ Platinum ELISA» и «Rat IL-6 Platinum ELISA» фирмы «еBioscience», Австрия.

После выведения животных из эксперимента забирался участок тканей спины, включающий зону отморожения, и 5 мм окружающих интактных тканей. Исследовали состояние поврежденных тканей на поверхности и разрезе, визуально учитывали особенности их строения. Для гистологического исследования брали 4-5 кусочков ткани из видимой области повреждения и из пограничной области. Кусочки ткани фиксировали в $10 \%$ растворе формалина на фосфатном буфере (pH 7,2-7,4) в течение двух недель, заливали в парафин, изготавливали срезы толщиной 4-5 мкм, окрашивали гематоксилином и эозином и по методу Ван Гизона.

Таблица 1

Количество животных в эксперименте

\begin{tabular}{|c|l|c|c|}
\hline \multirow{2}{*}{$\begin{array}{c}\text { № } \\
\text { ח/п }\end{array}$} & \multicolumn{1}{|c|}{ Характеристика групп } & \multicolumn{2}{|c|}{ Количество животных } \\
\cline { 3 - 4 } & \multicolumn{1}{|c|}{ общее } & $\begin{array}{c}\text { в т.ч. для изучения } \\
\text { летальности }\end{array}$ \\
\hline & Интактные животные & 60 & 60 \\
\hline & Контрольная группа 1 (модель некроза) & 60 & 60 \\
\hline & Контрольная группа 2 (модель некроза + некрэктомия) & 60 & 60 \\
\hline $\begin{array}{l}\text { Опытная группа (модель некроза + некрэктомия + комбинированное } \\
\text { применение серотонина адипината 4,5 мг/кг + DSLET 10 мкг/кг) }\end{array}$ & 60 & 60 \\
\hline Итого: & 240 & 240 \\
\hline
\end{tabular}


Динамика уровня биохимических показателей в контрольной группе 1 при экспериментальном контактном отморожении

\begin{tabular}{|c|c|c|c|c|c|}
\hline \multirow{2}{*}{$\begin{array}{c}\text { Биохимические } \\
\text { показатели }\end{array}$} & \multirow{2}{*}{$\begin{array}{c}\text { Исследуемые } \\
\text { группы }\end{array}$} & \multicolumn{4}{|c|}{ Сроки исследования } \\
\hline & & 1 сутки & 3 сутки & 7 сутки & 14 сутки \\
\hline \multirow{2}{*}{$\begin{array}{c}\text { МДА, } \\
\text { мкМоль/л }\end{array}$} & интактные & $1,8 \pm 0,05^{y}$ & $1,8 \pm 0,06^{y}$ & $2 \pm 0,08^{\mathrm{y}}$ & $1,98 \pm 1,98^{y}$ \\
\hline & контроль 1 & $3,26 \pm 0,16^{x}$ & $2,55 \pm 0,16^{x}$ & $2,94 \pm 0,06^{\mathrm{x}}$ & $2,48 \pm 0,1^{x}$ \\
\hline \multirow{2}{*}{$\begin{array}{l}\text { КАТ, } \\
\text { мкат/л }\end{array}$} & интактные & $8,28 \pm 0,24^{y}$ & $8,82 \pm 0,19^{y}$ & $9,12 \pm 0,18^{y}$ & $9,01 \pm 0,25^{\mathrm{y}}$ \\
\hline & контроль 1 & $8,99 \pm 0,24^{\mathrm{x}}$ & $11,43 \pm 0,43^{x}$ & $5,84 \pm 0,37^{\mathrm{x}}$ & $7,79 \pm 0,19^{x}$ \\
\hline \multirow{2}{*}{$\begin{array}{c}\text { СОД, } \\
\text { усл. ед./мл }\end{array}$} & интактные & $12,61 \pm 0,17^{\mathrm{y}}$ & $12,28 \pm 0,26^{\mathrm{y}}$ & $12,08 \pm 0,18^{\mathrm{y}}$ & $12,47 \pm 0,09^{\mathrm{y}}$ \\
\hline & контроль 1 & $8,25 \pm 0,15^{\mathrm{x}}$ & $9,12 \pm 0,22^{\mathrm{x}}$ & $9,93 \pm 0,35^{\mathrm{x}}$ & $12 \pm 0,2^{x}$ \\
\hline \multirow{2}{*}{$\begin{array}{c}\text { OAA, } \\
\%\end{array}$} & интактные & $28,23 \pm 0,56^{\mathrm{y}}$ & $27,84 \pm 0,46^{\mathrm{y}}$ & $27,49 \pm 0,39^{\mathrm{y}}$ & $28,15 \pm 0,37^{\mathrm{y}}$ \\
\hline & контроль 1 & $27,85 \pm 0,52^{x}$ & $33,35 \pm 0,68^{x}$ & $13,71 \pm 0,63^{\mathrm{x}}$ & $22,57 \pm 0,74^{\mathrm{x}}$ \\
\hline \multirow{2}{*}{$\begin{array}{c}\text { NOx, } \\
\text { мкМоль/л }\end{array}$} & интактные & $5,23 \pm 0,14^{y}$ & $5,35 \pm 0,15^{\mathrm{y}}$ & $5,26 \pm 0,13^{y}$ & $5,4 \pm 0,12^{\mathrm{y}}$ \\
\hline & контроль 1 & $3,62 \pm 0,14^{x}$ & $2,75 \pm 0,15^{x}$ & $3,19 \pm 0,16^{\mathrm{x}}$ & $3,46 \pm 0,19^{x}$ \\
\hline \multirow{2}{*}{$\begin{array}{l}\text { ИЛ-6, } \\
\text { пг/мЛ }\end{array}$} & интактные & $4,02 \pm 0,28^{y}$ & $4,36 \pm 0,23^{y}$ & $3,89 \pm 0,19^{y}$ & $4,14 \pm 0,23^{\mathrm{y}}$ \\
\hline & контроль 1 & $4,39 \pm 0,15^{\mathrm{xy}}$ & $24,32 \pm 0,7^{x}$ & $13,24 \pm 0,16^{\mathrm{x}}$ & $9,13 \pm 0,55^{\mathrm{x}}$ \\
\hline \multirow{2}{*}{$\begin{array}{c}\text { ФНО- } \alpha, \\
\text { пг/мЛ }\end{array}$} & интактные & $2,66 \pm 0,25^{y}$ & $2,4 \pm 0,15^{y}$ & $2,45 \pm 0,18^{y}$ & $2,26 \pm 0,15^{\mathrm{y}}$ \\
\hline & контроль 1 & $3,85 \pm 0,3^{x}$ & $16,24 \pm 0,74^{x}$ & $8,63 \pm 0,38^{x}$ & $5,85 \pm 0,37^{\mathrm{x}}$ \\
\hline
\end{tabular}

Примечание: ${ }^{\mathrm{y}}-\mathrm{p}<0,05$ в сравнении с контрольной группой $1 ;{ }^{\mathrm{x}}-\mathrm{p}<0,05$ в сравнении с интактной группой.

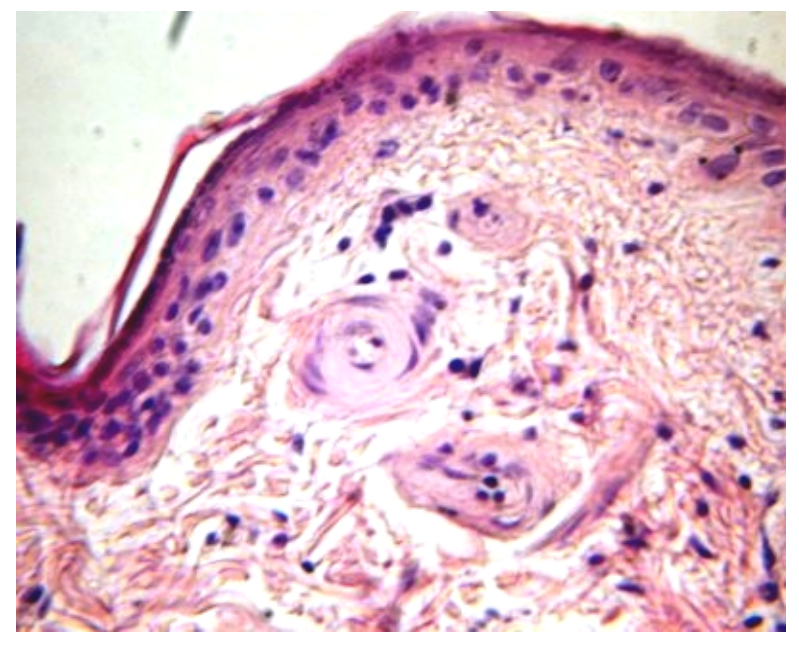

a

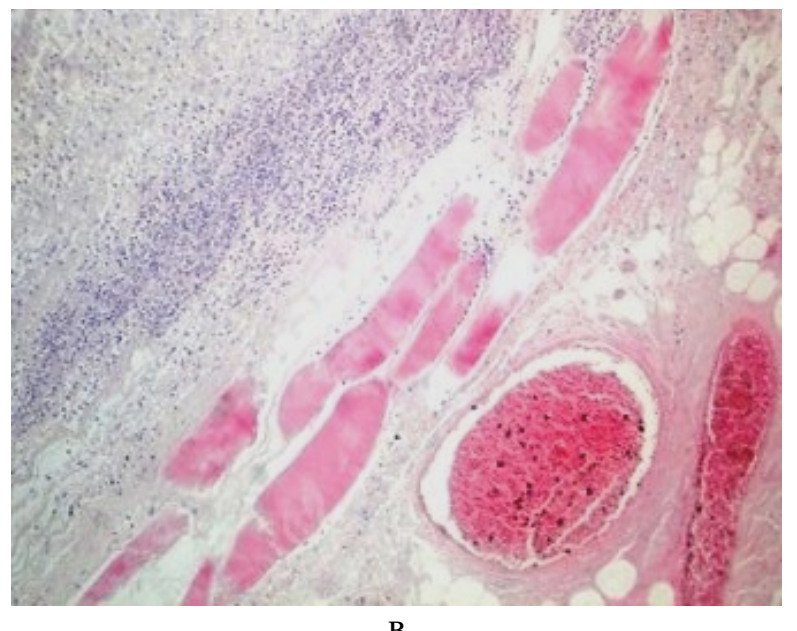

B

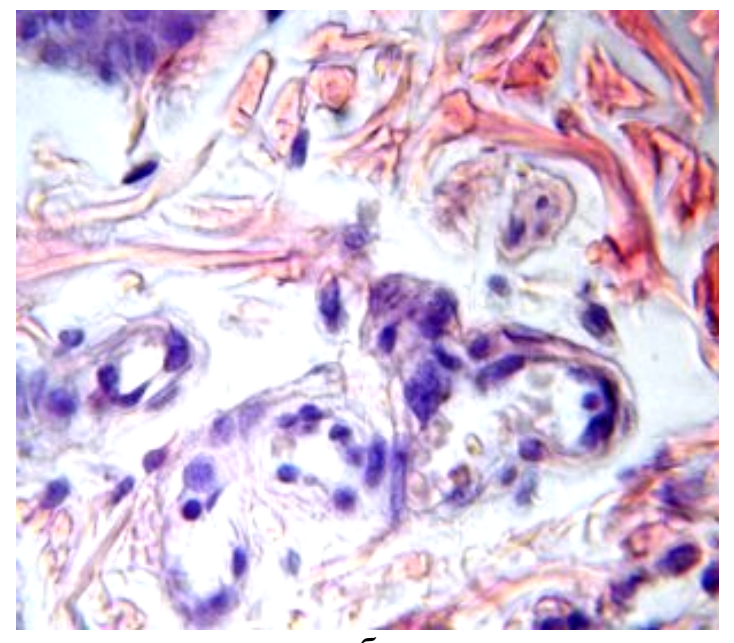

б

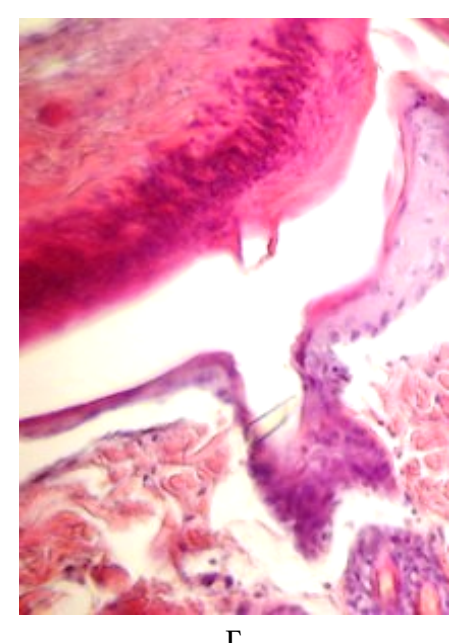

$\Gamma$

Рис. 1. Динамика морфологических изменений в контрольной группе 1 при экспериментальном контактном отморожении.

Примечание: а - гематоксилин-эозин. Ув. х 400; б - гематоксилин-эозин. Ув. х 400; в - гематоксилин-эозин. Ув. х 400; г - гематоксилин-эозин. Ув. х400. 
Летальность оценивалась в контрольных 1-2 группах и опытных 1-6 группах животных, получавших лечение, отдельно от основных экспериментальных групп. Процент летальности в каждой группе рассчитывался как отношение числа погибших животных к общему числу животных, взятых в эксперимент. После суммирования полученных результатов летальности на протяжении всего эксперимента к 14-м суткам рассчитывали общий процент летальности.

Статистическую обработку полученных данных проводили с использованием пакета прикладных программ StatSoft Statistica 6.1 Russian в соответствии с современными требованиями к исследованиям, выполняемым в рамках доказательной медицины, со стандартами GCP и GLP. Достоверность наблюдавшихся при действии исследованных препаратов изменений параметров как абсолютных, так и в процентах от исходного уровня, определяли путем расчета средней арифметической (М), ошибки средней арифметической $( \pm \mathrm{m})$ и оценки достоверности различий сравниваемых параметров между группами с использованием критерия Стьюдента для групп с разными дисперсиями, достоверными считались различия сравниваемых параметров при $\mathrm{p}<0,05$.

\section{РЕЗУЛЬТАТЫ ИССЛЕДОВАНИЯ И ИХ ОБСУЖДЕНИЕ}

При исследовании микроциркуляции кожи в пограничной некрозу зоне в первой контрольной группе выявлены значительные нарушения регионарного кровотока, сопровождающиеся достоверным снижением показателей микроциркуляции на первые, 3-и, 7-е и 14-е сутки исследования, с постепенным восстановлением микроциркуляции, начиная с 7-х суток, но при этом остававшихся достоверно ниже на $51,5 \%$ относительно группы интактных животных $(\mathrm{p}<0,05)$. Более выраженное восстановление уровня микроциркуляции в контрольной группе 1 имело место на 14-е сутки эксперимента, однако оставалось достоверно ниже нормы на $34,4 \%(\mathrm{p}<0,05)$

Нами также установлено, что в контрольной группе 1 на всех сроках исследования отмечалось достоверное повышение провоспалительных цитокинов. До конца эксперимента его значения не достигали уровня у интактных крыс.

В контрольной группе 1 через сутки после моделирования некроза поверхность поврежденной кожи некротизирована, происходит отслоение эпидермиса практически на всем протяжении области повреждения.

В сосочковом слое кожи выражен фибриноидный некроз соединительной ткани, в сетчатом слое дермы при окраске по методу Ван Гизон - набухание соединительнотканных волокон и стенок сосудов (рисунок 1a).

В пограничной области отмечается расслоение рогового слоя, клетки базального слоя эпидермиса, волосяных фолликулов и желез набухшие, в отдельных клетках - кариопикноз. В сосочковом слое наблюдаются запустевшие расширенные сосуды (рисунок 1б), стенки набухшие.

К 3-м суткам на поверхности области повреждения сформирован гомогенный слой некротических масс. Микроскопически эпидермис полностью слущен, сосочковый слой дермы разрушен.

К 7-м суткам на поверхности области повреждения формируется плотный струп. Глубокий некроз распространяется от эпидермиса до клетчатки (рисунок 1в).

Таким образом, в ходе проведенного эксперимента в контрольной группе 1 определяется развитие прогрессирующего некроза, распространяющегося на всю толщу кожи, подкожной клетчатки, захватывающего мышечную ткань. В пограничной некрозу области также развиваются очаги фибриноидного некроза, дистония сосудов, запустевание паретически расширенных и спавшихся сосудов, выраженная пролиферация эндотелия сосудов вплоть до их облитерации. Формируются рассеянные очаговые и диффузные воспалительные инфильтраты.

Репаративные процессы после холодовой травмы замедлены, персистируют некротические изменения. Формирование струпа в области повреждения макроскопически обнаруживается к 7-м суткам. К 7-м суткам появляются отдельные очаги развития молодой соединительной ткани, лишь к 14-м суткам зона некроза окружена грануляционной тканью, созревание ее замедлено.

Уровень летальности в контрольной группе 1 составил 47,5\%.

Динамика уровня биохимических показателей в контрольной группе 2 представлена в таблице 3.

Выполненная некрэктомия не приводила к снижению провоспалительных цитокинов, при этом уровень ИЛ-6 оставался достоверно выше в 2,6 раза на 7-е сутки и в 2,1 раза на 14 -е сутки эксперимента, а уровень ФНО- $\alpha$ был выше в 3,2 раза на 7-е сутки и в 2,1 раза на 14 -е сутки по сравнению с группой интактных животных (таблица 3).

На 3-и сутки в поверхностных слоях операционной раны выявляются очаги некроза мышечной ткани и жировой ткани. В пограничной области обнаруживаются инфильтраты, состоящие из нейтрофилов, макрофагов и плазмоцитов. Имеются очаги плазморрагии, небольшие свежие кровоизлияния. Имеются мелкие очаги формирования грануляционной ткани. 
Динамика уровня биохимических показателей в контрольной группе 2

\begin{tabular}{|c|c|c|c|}
\hline \multirow{2}{*}{$\begin{array}{c}\text { Биохимические } \\
\text { показатели }\end{array}$} & \multirow{2}{*}{ Исследуемые группы } & \multicolumn{2}{|c|}{ Сроки исследования } \\
\hline & & 7 сутки & 14 сутки \\
\hline \multirow{2}{*}{$\begin{array}{c}\text { МДА, } \\
\text { мкМоль/л }\end{array}$} & интактные & $1,93 \pm 0,10^{\mathrm{y}}$ & $1,94 \pm 0,14^{\mathrm{y}}$ \\
\hline & контроль 2 & $2,83 \pm 0,09^{x}$ & $2,50 \pm 0,11^{x}$ \\
\hline \multirow{2}{*}{$\begin{array}{l}\text { КАТ, } \\
\text { мкат/л }\end{array}$} & интактные & $9,12 \pm 0,13^{y}$ & $9,12 \pm 0,13^{y}$ \\
\hline & контроль 2 & $6,12 \pm 0,21^{x}$ & $7,75 \pm 0,26^{\mathrm{x}}$ \\
\hline \multirow{2}{*}{$\begin{array}{c}\text { СОД, } \\
\text { усл.ед./мл }\end{array}$} & интактные & $12,20 \pm 0,17^{\mathrm{y}}$ & $12,12 \pm 0,13$ \\
\hline & контроль 2 & $10,10 \pm 0,32^{x}$ & $11,66 \pm 0,24$ \\
\hline \multirow{2}{*}{$\begin{array}{c}\text { OAA, } \\
\%\end{array}$} & интактные & $25,80 \pm 0,76^{\mathrm{y}}$ & $26,90 \pm 0,80^{\mathrm{y}}$ \\
\hline & контроль 2 & $15,03 \pm 0,78^{x}$ & $23,67 \pm 0,66^{\mathrm{x}}$ \\
\hline \multirow{2}{*}{$\begin{array}{c}\text { NOx, } \\
\text { мкМоль/л }\end{array}$} & интактные & $5,59 \pm 0,14^{y}$ & $5,57 \pm 0,13^{y}$ \\
\hline & контроль 2 & $3,60 \pm 0,13^{x}$ & $4,17 \pm 0,18^{x}$ \\
\hline \multirow{2}{*}{$\begin{array}{l}\text { ИЛ-6, } \\
\text { пг/мл }\end{array}$} & интактные & $4,19 \pm 0,12^{y}$ & $4,25 \pm 0,15^{\mathrm{y}}$ \\
\hline & контроль 2 & $10,84 \pm 0,30^{\mathrm{x}}$ & $8,80 \pm 0,37^{\mathrm{x}}$ \\
\hline \multirow{2}{*}{$\begin{array}{l}\text { ФНО- } \alpha, \\
\text { пг/мл }\end{array}$} & интактные & $2,42 \pm 0,16^{y}$ & $2,32 \pm 0,11^{\mathrm{y}}$ \\
\hline & контроль 2 & $7,71 \pm 0,18^{x}$ & $4,78 \pm 0,32^{\mathrm{x}}$ \\
\hline
\end{tabular}

Примечание: ${ }^{\mathrm{y}}-\mathrm{p}<0,05$ в сравнении с контрольной группой $2 ;^{\mathrm{x}}-\mathrm{p}<0,05$ в сравнении с интактной группой.

К 7-м суткам в области раны по-прежнему выявляется очаг некроза, окруженный плотным демаркационным слоем нейтрофилов. Имеются мелкие очаги формирования грануляционной ткани с множественными фибробластами, тонкими новообразованными волокнистыми структурами.

К 14-м суткам в области операционной раны небольшой очаг некроза окружен формирующейся молодой соединительной тканью с большим количеством активных фибробластов, тонкими новообразованными коллагеновыми волокнами. Соединительная ткань, окружающая зону некроза, рыхлая, отечная, выталкивает некротические массы на поверхность. Вблизи области повреждения новообразованные сосуды грануляционной ткани содержат форменные элементы крови.

Таким образом, в ходе проведенного эксперимента в контрольной группе 2 репаративные процессы замедлены, персистируют некротические изменения. Формирование струпа в области повреждения макроскопически обнаруживается к 7-м суткам, также, как и формирование демаркационной зоны вокруг некротизированных тканей. К 7-м суткам появляются отдельные очаги развития молодой соединительной ткани, лишь к 14-м суткам зона некроза окружена грануляционной тканью, созревание ее замедлено.

Уровень летальности в контрольной группе 2 составил $30 \%$.

Динамика уровня биохимических показателей в опытной группе представлена в таблице 4.

Введение экспериментальным животным комбинации серотонина адипината и DSLET привело к повышению уровня каталазы в опытной группе на $41,3 \%$ на 7 -е сутки и на $19,1 \%$ на 14 -е сутки эксперимента относительно контрольной группы $2(\mathrm{p}<0,05)$. Следует отметить, что на 7-е и 14-е сутки уровень каталазы не отличался от значения интактных животных $(\mathrm{p}>0,05)$ (таблица 4).

$\mathrm{B}$ опытной группе, получающей лечение комбинацией серотонина адипината и DSLET, активность СОД превосходит на 7-е и 14-е сутки эксперимента на $31,8 \%$ и 7,3\% соответственно контрольную группу $2(\mathrm{p}<0,05)$ и не отличается от значений интактных животных $(\mathrm{p}>0,05)$ (таблица 4).

В группе животных, получавших комбинацию серотонина адипината и DSLET, начиная с 7-х суток отмечается увеличение уровня ОАА на $64,6 \%$ и $18,3 \%$ на 14 -е сутки исследования по сравнению с контрольной группой $2(\mathrm{p}<0,05)$. Во время эксперимента значения ОАА не отличались от группы интактных животных на всех сроках исследования ( $>0,05)$ (таблица 4).

В контрольной группе 2 имело место нарушение NO-продуцирующей функции эндотелия, выражающееся в снижении концентрации конечных стабильных метаболитов оксида азота (NOx) на 7 -е и 14 -е сутки эксперимента на $35,6 \%$ и $25,1 \%$ соответственно, по сравнению с группой интактных животных $(\mathrm{p}<0,05)$.

Применение в эксперименте комбинации препаратов выявило их положительное влияние на уровень NOx на 7-е и 14-е сутки исследования. Отмечено повышение данного показателя в опытной группе 6 на $33,6 \%$ и на $26,4 \%$ на 7 -е и 14-е сутки соответственно по сравнению с контрольной группой $2(\mathrm{p}<0,05)$. При этом на 14-е сутки повышение концентрации конечных стабильных метаболитов оксида азота достигает уровня интактных крыс (p>0,05). 
Динамика биохимических показателей в опытной группе

\begin{tabular}{|c|c|c|c|}
\hline \multirow{2}{*}{$\begin{array}{c}\text { Биохимические } \\
\text { показатели }\end{array}$} & \multirow{2}{*}{ Исследуемые группы } & \multicolumn{2}{|c|}{ Сроки исследования } \\
\hline & & 7 сутки & 14 сутки \\
\hline \multirow{3}{*}{$\begin{array}{c}\text { МДА, } \\
\text { мкМоль/л }\end{array}$} & Интактные & $1,93 \pm 0,10^{y}$ & $1,94 \pm 0,14^{y}$ \\
\hline & Контроль 2 & $2,83 \pm 0,09^{x}$ & $2,50 \pm 0,11^{\mathrm{x}}$ \\
\hline & Опытная группа 6 & $2,11 \pm 0,06^{\mathrm{y}}$ & $1,93 \pm 0,07^{\mathrm{y}}$ \\
\hline \multirow{3}{*}{$\begin{array}{l}\text { КАТ, } \\
\text { мкат/л }\end{array}$} & Интактные & $9,12 \pm 0,13^{y}$ & $9,12 \pm 0,13^{\mathrm{y}}$ \\
\hline & Контроль 2 & $6,12 \pm 0,21^{x}$ & $7,75 \pm 0,26^{\mathrm{x}}$ \\
\hline & Опытная группа 6 & $8,65 \pm 0,21^{y}$ & $9,23 \pm 0,18^{y}$ \\
\hline \multirow{3}{*}{$\begin{array}{c}\text { СОД, } \\
\text { усл.ед./мл }\end{array}$} & Интактные & $12,20 \pm 0,17^{\mathrm{y}}$ & $12,12 \pm 0,13$ \\
\hline & Контроль 2 & $10,10 \pm 0,32^{x}$ & $11,66 \pm 0,24$ \\
\hline & Опытная группа 6 & $13,31 \pm 0,24^{\mathrm{xy}}$ & $12,51 \pm 0,18^{\mathrm{y}}$ \\
\hline \multirow{3}{*}{$\begin{array}{c}\text { OAA, } \\
\%\end{array}$} & Интактные & $25,80 \pm 0,76^{\mathrm{y}}$ & $26,90 \pm 0,80^{y}$ \\
\hline & Контроль 2 & $15,03 \pm 0,78^{x}$ & $23,67 \pm 0,66^{x}$ \\
\hline & Опытная группа 6 & $24,74 \pm 0,52^{\mathrm{y}}$ & $28,00 \pm 0,64^{\mathrm{y}}$ \\
\hline \multirow{3}{*}{$\begin{array}{c}\text { NOx, } \\
\text { мкМоль/л }\end{array}$} & Интактные & $5,59 \pm 0,14^{y}$ & $5,57 \pm 0,13^{\mathrm{y}}$ \\
\hline & Контроль 2 & $3,60 \pm 0,13^{x}$ & $4,17 \pm 0,18^{x}$ \\
\hline & Опытная группа 6 & $4,81 \pm 0,17^{\mathrm{xy}}$ & $5,27 \pm 0,20^{y}$ \\
\hline \multirow{3}{*}{$\begin{array}{l}\text { ИЛ-6, } \\
\text { пг/мЛ }\end{array}$} & Интактные & $4,19 \pm 0,12^{y}$ & $4,25 \pm 0,15^{y}$ \\
\hline & Контроль 2 & $10,84 \pm 0,30^{\mathrm{x}}$ & $8,80 \pm 0,37^{\mathrm{x}}$ \\
\hline & Опытная группа 6 & $4,24 \pm 0,22^{y}$ & $3,89 \pm 0,18^{\mathrm{y}}$ \\
\hline \multirow{3}{*}{$\begin{array}{c}\text { ФНО- } \alpha, \\
\text { пг/мл }\end{array}$} & Интактные & $2,42 \pm 0,16^{y}$ & $2,32 \pm 0,11^{\mathrm{y}}$ \\
\hline & Контроль 2 & $7,71 \pm 0,18^{x}$ & $4,78 \pm 0,32^{\mathrm{x}}$ \\
\hline & Опытная группа 6 & $2,84 \pm 0,19^{y}$ & $2,54 \pm 0,15^{y}$ \\
\hline
\end{tabular}

Примечание: ${ }^{\mathrm{y}}-\mathrm{p}<0,05$ в сравнении с контрольной группой $2 ;^{\mathrm{x}}-\mathrm{p}<0,05$ в сравнении с интактной группой.

В опытной группе применение комбинированного лечения привело к снижению уровня провоспалительных цитокинов, так уровень ИЛ-6 снижался в 2,6 раза на 7-е сутки и в 2,3 раза на 14-е сутки эксперимента относительно контрольной группы $2(\mathrm{p}<0,05)$.

В таблице представлены данные, демонстрирующие снижение ФНО- $\alpha$ в опытной группе в 2,7 на 7 -е сутки и в 1,9 раза на 14 -е сутки исследования по сравнению с контрольной группой $2(\mathrm{p}<0,05)$.

Следует отметить, что уровень провоспалительных цитокинов ИЛ-6 и ФНО- $\alpha$ в опытной группе на 7-е и 14-е сутки эксперимента снижался до значений интактных животных $(\mathrm{p}>0,05)$.

При комбинированном использовании препаратов серотонина адипинат и DSLET на 3-и сутки в области операционной раны демаркационная зона становится макроскопически видимой, при микроскопическом исследовании некротические массы не выявляются, обнаруживается жировая ткань с небольшими клеточными инфильтратами (рисунок 3a), а также тонким слоем грануляционной ткани с большим количеством макрофагов и фибробластов. В межмышечной соединительной ткани обнаруживаются единичные небольшие скопления нейтрофилов. Сосуды расширены, гиперемированы, стенки набухшие, в просветах - стаз. Выражен отек тканей.

К 7-м суткам на поверхности раны обнаруживается толстый слой грануляционной ткани, богатой фибробластами, макрофагами с примесью нейтрофилов. Имеются очаги скопления плотных новообразованных соединительнотканных волокон (рисунок 3б, в).

К 14-м суткам формируется плотная соединительная ткань, богатая зрелыми волокнистыми структурами (рисунок Зг).

Использование комбинации препаратов серотонина адипинат и DSLET позволяет морфологически (макроскопически) определять зону демаркации на 3-и сутки и проводить адекватную некрэктомию в пределах границ некроза. При микроскопическом исследовании на 3-и сутки некротические массы отсутствуют, имеются небольшие воспалительные клеточные инфильтраты. В краях раны формируется грануляционная ткань. К 7-м суткам слой грануляций утолщается, накапливаются плотные соединительнотканные волокна, к 14-м суткам формируется зрелая волокнистая соединительная ткань. 


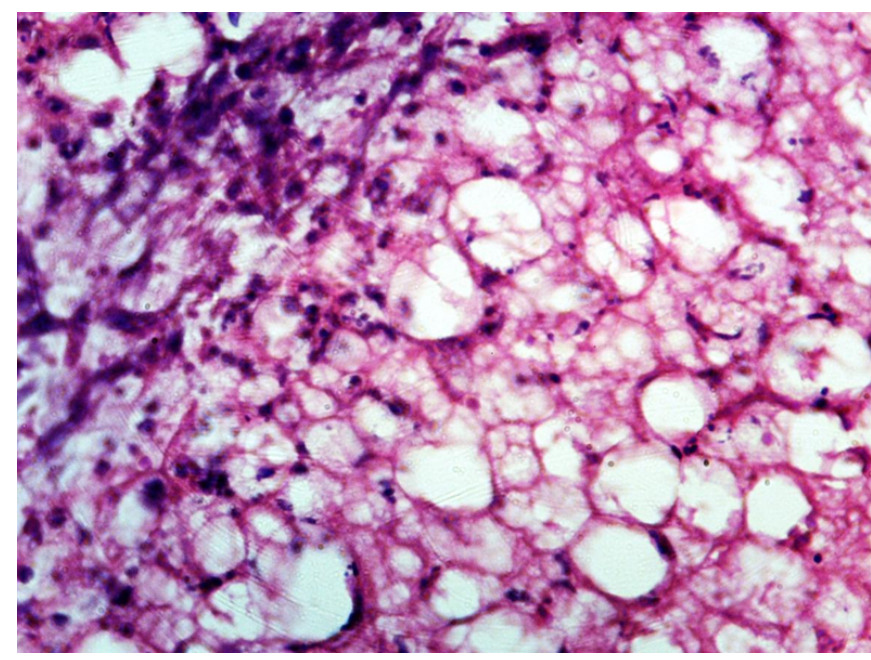

a

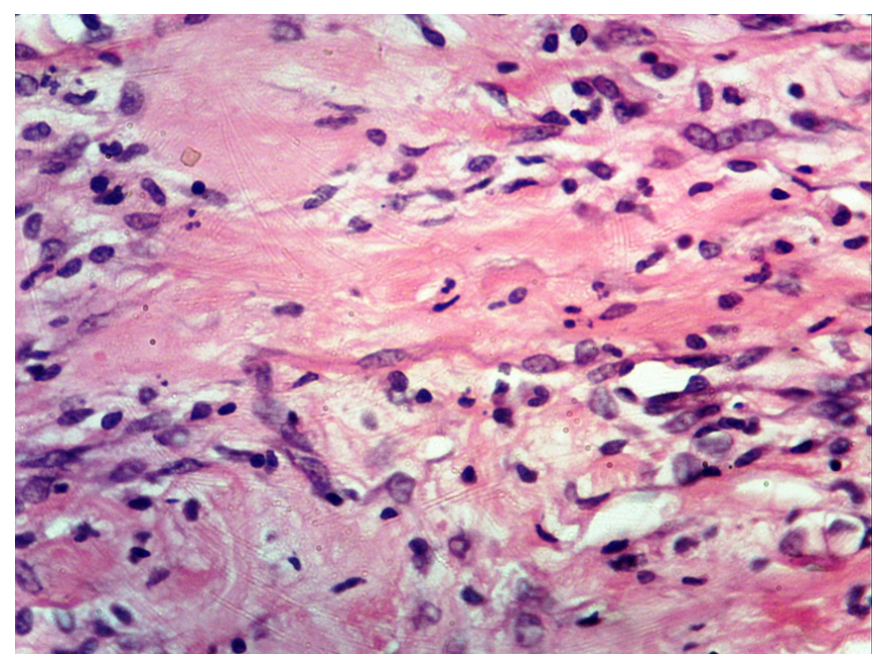

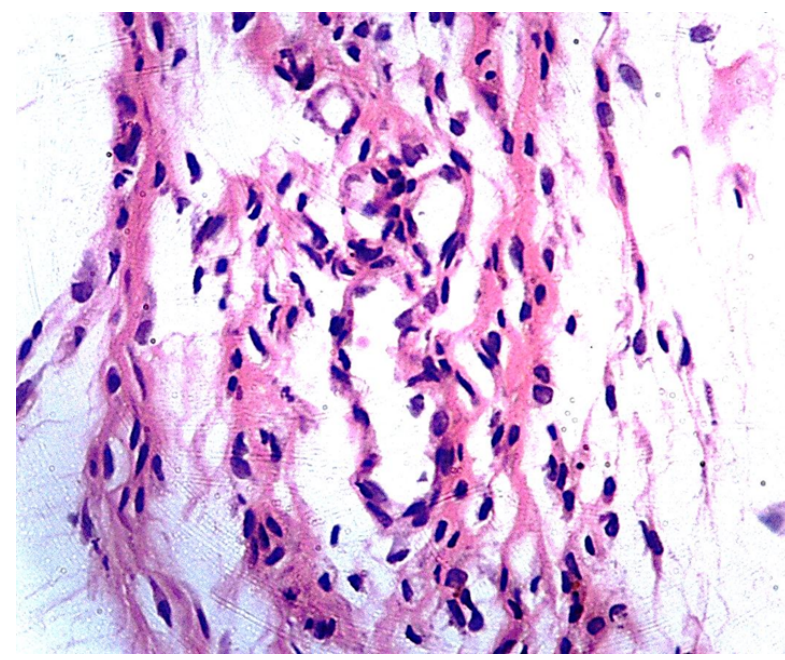

6

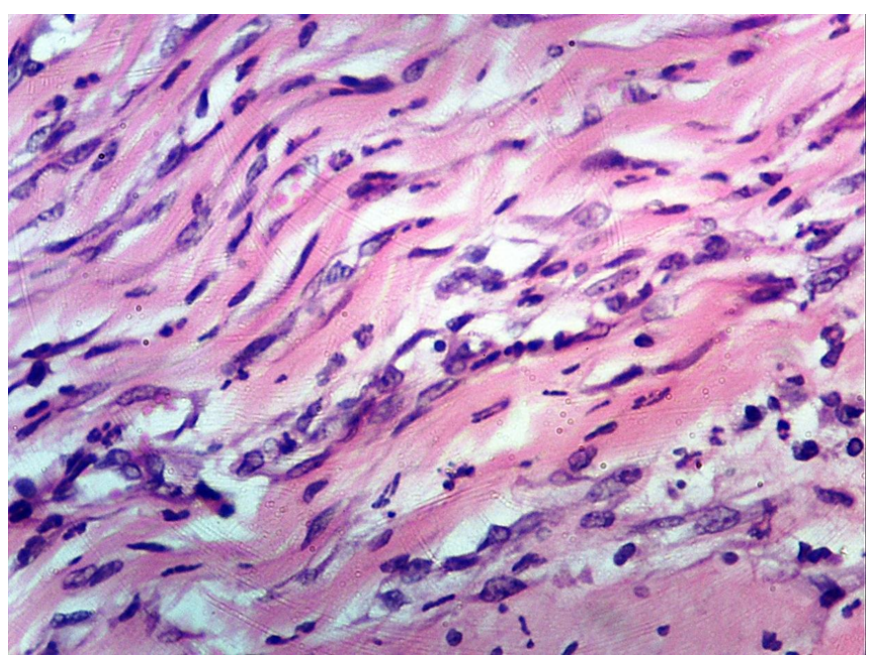

Рис. 3. Динамика морфологических изменений в опытной группе 6 после некрэктомии на фоне применения комбинации серотонина адипината и DSLET при экспериментальном контактном отморожении.

Примечание: а - гематоксилин-эозин. Ув х 200; б - гематоксилин-эозин. Ув х 400; в - гематоксилин-эозин. Ув х 400; г-гематоксилин-эозин. Ув х 400.

В опытной группе после выполнения некрэктомии с использованием комбинации серотонина адипината и DSLET из 30 животных погибло 4 животных, что составило 13,3\% летальности. За 4-7-е сутки эксперимента летальность составила 3,3\%. За 8-14-е сутки летальность экспериментальных животных не наблюдалась. Следовательно, из выше представленных данных получено, что общая летальность в опытной группе составила $16,6 \%$.

Таким образом, некрэктомия в раннем периоде травматической болезни на фоне комбинированного введения в послеоперационном периоде серотонина адипината и препарата DSLET позволяет уменьшить объем некроза глубоких тканей и улучшить выживаемость экспериментальных животных по сравнению с контрольной группой.

\section{ЛИТЕРАТУРА}

1. Бойко В.В. Изучение морфологических особенностей в тканях экспериментальных животных при моделировании холодовой травмы // Вестник морфологии. - 2010. - № 16(3). - С. 526-528.

2. Горпинич А.Б. Применение серотонина адипината в лечении пациентов с критической ишемией нижних конечностей // Ученые записки Орловского государственного университета. Серия: Естественные, технические и медицинские науки. - 2008. № 2. - C. 91-96.

3. Квачахия Л.Л., Лазаренко В.А., Моновцчов И.А. Дозозависимые иммунные эффекты «Риботана» при экспериментальной ожоговой травме // Вестник новых медицинских технологий. - 2006. T. XIII, № 3. - C. 31-32.

4. Лазаренко В.А., Артюшкова Е.Б., Мишустин В.Н., Моновцчов И.А., Квачахия Л.Л., Чигунадзе А.Л., Артюшкова E.B. Перспектива применения активной хирургической тактики на фоне введения ком- 
бинации опиоидного пептида DSLET и серотонинергического средства серотонина адипината в комплексном лечении контактного отморожения в эксперименте [Электронный ресурс] // Современные проблемы науки и образования. - 2013. - № 6 . - Режим доступа: http://www.scienceeducation.ru/ru/article/view?id=10991, (18.05.2016)
5. Чигунадзе А.Л., Артюшкова Е.Б., Мишустин В.Н., Горяинова Г.Н., Артюшкова Е.В., Гладченко М.П., Уханова И.Ю., Заугольникова Н.С. Оценка фармакологической эффективности применения серотонина адипината, опиоидного пептида DSLET и их комбинации при экспериментальном контактном отморожении на фоне активной хирургической тактики // Курск. науч.-практ. вестн. «Человек и его здоровье». - 2015. - № 2. C. 89-95. 